\title{
Profiles of amino-acid utilisation and production amongst strains of Branhamella catarrhalis
}

\author{
V. BEZJAK, H. N. SHAH and "J. BARLEY \\ Departments of Microbiology and "Biochemistry, Faculty of Medicine, PO Box 24923 Safat, Kuwait University, \\ 13110 Kuwait
}

\begin{abstract}
Summary. Utilisation and production of amino acids by isolates of Branhamella catarrhalis was studied by ion exchange chromatography after cells had been grown in nutrient broth and Mueller-Hinton broth. The profiles of amino acids used and produced by each strain were compared by a single linkage cluster algorithm. The results of this study reflect the biochemical and physiological heterogeneity amongst strains of $B$. catarrhalis.
\end{abstract}

\section{Introduction}

Gram-negative aerobic cocci belonging to the species Branhamella catarrhalis form part of the normal nasopharyngeal flora of man but are also frequently associated with upper respiratory tract infections (Coffey et al., 1967; Ninane et al., 1978; Bøvre and Hagen, 1981). Since the first report of penicillin resistance amongst strains of $B$. catarrhalis (Malmvall et al., 1977), $\beta$-lactamase-producing strains have been isolated with increasing frequency (Kamme et al., 1983). These organisms are characterised by their inability to utilise carbohydrates as a source of energy. Consequently, many chemotaxonomic markers, such as the presence of long chain fatty acids (Jantzen et al., 1974; Jantzen and Bryn, 1985), and genetic studies (Kingsbury, 1967) have been valuable in defining species. The DNA base composition of all strains so far examined is $40-43 \mathrm{mols} \% \mathrm{G}+\mathrm{C}$ (Bøvre, 1984).

Early observations on the metabolism of $B$. catarrhalis highlighted the importance of aminoacid catabolism (Fitting and Scherp, 1950). In particular, glutamic acid and alanine were metabolised by washed cells with the liberation of ammonia, $\mathrm{CO}_{2}$ and keto acids. Attempts were subsequently made to use amino acids as nutritional markers (Otero, 1972). We have investigated several closely-related strains of $\boldsymbol{B}$. catarrhalis to evaluate amino-acid uptake and production profiles as possible biochemical markers for studying strain variation that is not readily detected by chemotaxonomic methods.

Received 25 June 1987; accepted 10 Nov. 1987.

\section{Materials and methods}

\section{Bacteria}

The following bacterial strains isolated by $\mathrm{Dr} \mathrm{C}$. Kamme (Department of Medical Microbiology, University of Lund, Sweden) were used: B. catarrhalis strains 1 , 3, 4, 5 and 6 (penicillin-resistant, plasmid-mediated) and 65C and R-235 (penicillin-sensitive). All strains were cultured on blood-agar plates (Oxoid No. 2), then incubated at $37^{\circ} \mathrm{C}$ overnight and stored at $4^{\circ} \mathrm{C}$ for $7-10$ days when fresh subcultures were made.

\section{Growth in liquid media for amino-acid profiles}

Nutrient broth (NB) (Oxoid) and Mueller-Hinton broth (MH) (Oxoid) were used to assess the uptake or production of amino acids. From an overnight bloodagar culture a suspension was made in nutrient broth to a density of $c$. $(2-4) \times 10^{12}$ cells/L; $1 \mathrm{ml}$ of bacterial suspension was inoculated into $100-\mathrm{ml}$ volumes of NB and $\mathrm{MH}$, mixed, and a 2-ml sample $(0 \mathrm{~h})$ withdrawn. Thereafter, flasks were incubated with shaking at $37^{\circ} \mathrm{C}$ for $24 \mathrm{~h}$. Further 2-ml samples were withdrawn after $5 \mathrm{~h}$ and at the end of incubation $(24 \mathrm{~h})$. Viable cell counts were made by the luminescence ATP technique as described by Dupont Instruments with a Lumac NRB (cell content releasing agent) extraction procedure (Chappelle and Levin, 1968). The samples were membranefiltered to remove bacteria and stored at $-25^{\circ} \mathrm{C}$ until amino-acid analysis.

\section{Amino-acid analysis}

Amino-acid analysis was performed by ion exchange chromatography with a Beckman $119 \mathrm{cl}$ amino-acid analyser. A single column was used with lithium citrate elution buffers of $p \mathrm{H} 2.83,3.70$ and 3.75 respectively. Before analysis, samples were diluted with equal volumes 
Table I. Results of amino-acid analyses of $B$. catarrhalis strains in relation to culture medium

\begin{tabular}{|c|c|c|c|c|}
\hline \multirow[b]{3}{*}{ Strain no. } & \multicolumn{4}{|c|}{ Amino acids } \\
\hline & \multicolumn{2}{|c|}{ utilised in } & \multicolumn{2}{|r|}{ produced in } \\
\hline & NB & MH & NB & MH \\
\hline $\begin{array}{l}1 \\
3 \\
4 \\
5 \\
6 \\
65 C \\
\text { R-235 }\end{array}$ & $\begin{array}{l}\text { C } \\
\text { B, C, D, E, F } \\
\text { C, I, J } \\
\text { B, C, E, F } \\
\text { C } \\
\text { A, B, C, E, F } \\
\text { C }\end{array}$ & $\begin{array}{l}\text { none } \\
\text { A, B, C, D, E, F } \\
\text { A, D, I, J } \\
\text { B, C, D, E } \\
\text { A, B, C, D, E } \\
\text { C, D, E } \\
\text { B, C, D, E }\end{array}$ & $\begin{array}{l}\text { H } \\
\text { none } \\
\text { none } \\
\mathrm{G}, \mathrm{H} \\
\mathrm{G}, \mathrm{H} \\
\mathrm{G}, \mathrm{H}, \mathrm{N} \\
\mathrm{G}, \mathrm{H}, \mathrm{N}\end{array}$ & 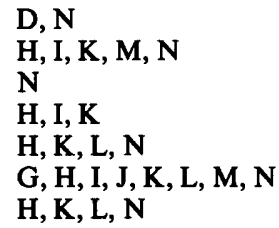 \\
\hline
\end{tabular}

$\mathrm{A}=$ aspartic acid, $\mathrm{B}=$ serine, $\mathrm{C}=$ glutamic acid, $\mathrm{D}=$ proline, $\mathrm{E}=$ glycine, $\mathrm{F}=$ histidine, $\mathrm{G}=$ threonine, $\mathrm{H}=$ valine, $\mathrm{I}=$ cystine, $\mathrm{J}=$ methionine, $\mathrm{K}=$ isoleucine, $\mathrm{L}=$ phenylalanine, $\mathrm{M}=$ ornithine, $\mathrm{N}=$ lysine.

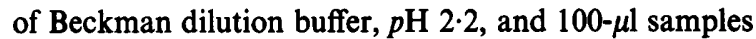
were applied to the column. The calibration standard mixture was supplied by the Pierce Chemical Company.

Samples analysed represented cell-free filtrates of each culture after incubation for $5 \mathrm{~h}$ and $24 \mathrm{~h}$, and of inoculated media before incubation; two additional samplesuninoculated NB and MH, which served as blankswere also analysed. All the results of amino-acid determinations were expressed in $\mathrm{nmol} / \mathrm{ml}$. To evaluate these and to determine which amino acids were utilised or produced, a value of $50 \%$ above or below the control was arbitrarily taken as production or uptake, respectively, for each amino acid.

\section{Computer analysis}

The similarities between strains were assessed by a simple single linkage programme which derived the amalgamation distances between strains from all the data from the amino-acid utilisation and production profiles. The biomedical package (Dixon, 1985) was used for these analyses, as described by Shah et al. (1987).

\section{Results}

Since there were only minor quantitative differences in amino-acid utilisation or production between $0-\mathrm{h}$ and 5-h samples, the results obtained with only $24-\mathrm{h}$ samples were recorded. The profile of amino-acid uptake or production was constant for each strain in a particular medium. The results of the analyses of the 24-h samples are shown in table I and quantitative data for one amino acid are given in table II. Strains of $\boldsymbol{B}$. catarrhalis utilised up to six amino acids and produced up to eight amino acids when grown in two different media (table I). Glutamic acid was used by all strains grown in NB whereas proline, glycine and glutamic acid were used by most strains grown in MH.

Generally, more amino acids were utilised in MH than in NB (table I). Strain 6, for example, assimilated only glutamic acid in NB whereas aspartic acid, serine, glutamic acid, proline and glycine were taken up in MH (table I). Glutamic acid was the most readily utilised amino acid. In NB, all strains used this amino acid and all but strains 1 and 4 utilised it in MH. For strains 1, 6, and R-235 incubated in NB, glutamic acid was the only amino acid utilised (table I). Threonine, valine, isoleucine, lysine and phenylalanine were not taken up from either medium. Cystine and methionine were taken up from both media by strain 4 . Thus a preference for assimilating sulphur-containing amino acids clearly characterises this strain.

All isolates except strain 4 produced valine in

Table II. Quantitative utilisation of serine as an example of an amino acid used to different extents in NB and MH by strains of $B$. catarrhalis

\begin{tabular}{l|cccc}
\hline & \multicolumn{3}{|c}{ Serine utilised (nmols/ml) at } \\
\cline { 3 - 4 } $\begin{array}{l}\text { Strain } \\
\text { no. }\end{array}$ & Medium & $0 \mathrm{~h}$ & $24 \mathrm{~h}$ & $\begin{array}{c}\text { Percentage } \\
\text { reduction }\end{array}$ \\
\hline 3 & MH & 3121 & 635 & 80 \\
& NB & 440 & 149 & 66 \\
5 & MH & 3819 & 1246 & 67 \\
& NB & 392 & 131 & 67 \\
6 & MH & 4086 & 886 & 77 \\
$65 C$ & NB & 472 & 107 & 77 \\
R235 & MH & 3369 & 0 & 100 \\
& & & & \\
\hline
\end{tabular}


Table III. Profile of amino-acid uptake and production by a selected strain (no. 3) of $B$. catarrhalis grown in NB and $\mathrm{MH}$ for $24 \mathrm{~h}$

\begin{tabular}{|c|c|c|c|}
\hline \multirow[b]{2}{*}{ Amino acid } & \multicolumn{2}{|c|}{$\begin{array}{l}\text { Amount of amino acid } \\
(\mathrm{nmols} / \mathrm{ml}) \text { at }\end{array}$} & \multirow{2}{*}{$\begin{array}{l}\text { Change in } \\
\text { amount }\end{array}$} \\
\hline & $0 \mathrm{~h}$ & $24 \mathrm{~h}$ & \\
\hline \multicolumn{4}{|l|}{$N B$} \\
\hline phosphoserine & $94 \cdot 18$ & $83 \cdot 50$ & $\cdots$ \\
\hline threonine & 298.40 & $441 \cdot 46$ & $\ldots$ \\
\hline serine & $440 \cdot 50$ & $149 \cdot 72$ & decrease \\
\hline proline & $209 \cdot 80$ & 0.0 & decrease \\
\hline glycine & $1209 \cdot 64$ & 404.90 & decrease \\
\hline alanine & $1216 \cdot 40$ & $820 \cdot 24$ & $\ldots$ \\
\hline valine & $331 \cdot 38$ & 673.62 & $\ldots$ \\
\hline cysteine & $46 \cdot 20$ & $38 \cdot 74$ & $\ldots$ \\
\hline methionine & $153 \cdot 70$ & $170 \cdot 50$ & $\ldots$ \\
\hline isoleucine & $226 \cdot 20$ & 304.04 & $\ldots$ \\
\hline leucine & $667 \cdot 14$ & $722 \cdot 12$ & $\ldots$ \\
\hline tyrosine & $143 \cdot 74$ & $157 \cdot 62$ & $\ldots$ \\
\hline phenylalanine & $229 \cdot 78$ & $253 \cdot 40$ & $\ldots$ \\
\hline ornithine & $159 \cdot 10$ & $137 \cdot 56$ & $\ldots$ \\
\hline lysine & $377 \cdot 18$ & $476 \cdot 70$ & $\ldots$ \\
\hline histidine & 59.56 & $27 \cdot 08$ & decrease \\
\hline arginine & NR & $292 \cdot 10$ & $\ldots$ \\
\hline glutamic acid & $458 \cdot 14$ & $\operatorname{tr}$ & decrease \\
\hline aspartic acid & $337 \cdot 74$ & $182 \cdot 62$ & $\ldots$ \\
\hline \multicolumn{4}{|l|}{$M H$} \\
\hline phosphoserine & $360 \cdot 0$ & $344 \cdot 16$ & $\cdots$ \\
\hline threonine & $1910 \cdot 1$ & $2537 \cdot 0$ & $\ldots$ \\
\hline serine & $3121 \cdot 9$ & $635 \cdot 64$ & decrease \\
\hline proline & $4823 \cdot 2$ & $206 \cdot 16$ & decrease \\
\hline glycine & $1968 \cdot 0$ & 143.94 & decrease \\
\hline alanine & $2923 \cdot 2$ & $1860 \cdot 54$ & $\ldots$ \\
\hline valine & $1914 \cdot 8$ & $4432 \cdot 4$ & increase \\
\hline cysteine & $36 \cdot 6$ & $68 \cdot 7$ & increase \\
\hline methionine & $994 \cdot 2$ & 1489.96 & $\ldots$ \\
\hline isoleucine & 1065.66 & $2445 \cdot 8$ & increase \\
\hline leucine & $3554 \cdot 0$ & 5232.0 & $\ldots$ \\
\hline tyrosine & $957 \cdot 0$ & 1303.94 & $\ldots$ \\
\hline phenylalanine & $1540 \cdot 58$ & $2118 \cdot 40$ & $\ldots$ \\
\hline ornithine & $229 \cdot 08$ & 454.90 & increase \\
\hline lysine & $3188 \cdot 0$ & $4866 \cdot 0$ & increase \\
\hline histidine & $520 \cdot 58$ & $148 \cdot 80$ & decrease \\
\hline arginine & 957.88 & $712 \cdot 0$ & $\cdots$ \\
\hline glutamic acid & $7896 \cdot 4$ & $1198 \cdot 56$ & decrease \\
\hline aspartic acid & 4116.02 & $1778 \cdot 50$ & decrease \\
\hline
\end{tabular}

$\mathrm{NR}=$ not resolved $; \mathrm{tr}=$ trace.

NB or MH or both. Strain $65 \mathrm{C}$ had the most complex profile in $\mathrm{MH}$; it produced threonine, valine, cysteine, methionine, isoleucine, phenylalanine, ornithine and lysine. The profile of amino acids produced by each strain was distinct; nutritionally, strain 4 was the least related to the remaining strains (table I). Most strains used five or six amino acids; strain $65 \mathrm{C}$ was characterised by an abnormally high level of amino acid production. An example of a detailed profile of uptake and production in both media is shown in table III. The inter-relationships between strains by comparison of the profiles of amino acids used and produced were ascertained by a single linkage dendrogram (not shown). Strains 6 and R-235 were almost identical and were related to each other at the $98 \%$ similarity level. Strains 3 and 5 were related to each other at the $63 \%$ level of similarity and were more closely related to strains 6 and R-235 than to the other strains. Strains 1,4 , and $65 \mathrm{C}$ had only a low affinity with the other strains, and amongst themselves, and must represent different nutritional biotypes within the species.

\section{Discussion}

It is evident that there were significant differences between cultures of the same strain grown in NB and $\mathrm{MH}$, indicating that peptides in the medium may suppress the uptake or production of certain amino acids. $B$. catarrhalis utilises a simple range of free amino acids but the profile obtained for each strain is a distinctive feature. The common occurrence of glutamic acid uptake by the test strains is in agreement with the data of Fitting and Scherp (1950) who reported the rapid uptake of glutamic acid by cell suspensions. Furthermore, Dent (1982) reported four types of glutamate dehydrogenase electrophoretic patterns amongst seven strains. The present data lend further support for heterogeneity amongst strains of $\boldsymbol{B}$. catarrhalis.

Our method of identifying nutritional variants of $B$. catarrhalis is reliable and could be valuable in biochemical and physiological studies. Similar studies in which identical techniques were used have been reported with amino acid-fermenting clostridia (Mead, 1971). Recent advances in high performance liquid chromatographic techniques (see for example, Harpold et al., 1985) would make nutritional biotyping of strains of $B$. catarrhalis more feasible for future studies.

We thank Dr C. Kamme, Department of Medical Microbiology, University of Lund, for providing us with strains of $B$. catarrhalis obtained during his mutational studies. The help of Mr A. Nemeth, Consultant of the Computer Center at the Faculty of Medicine, Kuwait, in constructing the programme to analyse amino-acid data is greatly appreciated and we are also grateful to Dr Senthilselvan for his help with similarity analyses. 


\section{REFERENCES}

Bøvre K 1984 Subgenus Branhamella (Catlin 1970) Bøvre 1979 $404^{\mathrm{VP}}$ In: Krieg N R, Holt J G (eds) Bergey's manual of systematic bacteriology, 9th edn. Williams and Wilkins, Baltimore, pp 302-303.

Bøvre K, Hagen N 1981 In: Starr et al. (eds) The Prokaryotes: a handbook on habitats, isolation and identification of bacteria. Springer Verlag, Berlin. pp 1506-1529.

Chappelle E W, Levin G V 1968 Use of the firefly bioluminescent reaction for rapid detection and counting of bacteria. Biochemical Medicine 2: 41-52.

Coffey J D, Martin A D, Booth H N 1967 Neisseria catarrhalis in exudate otitis media. Archives of Otolaryngology 86: 403406.

Dent V E 1982 Identification of oral Neisseria species of animals. Journal of Applied Bacteriology 52: 21-30.

Dixon W P (ed) 1985 Statistical Software. University of California Press, Berkeley, CA.

Fitting C, Scherp H W 1950 Observations on the metabolism of a strain of Neisseria catarrhalis. Journal of Bacteriology 59: 277-286.

Harpold D J, Wasilauskas B L, O'Connor M L 1985 Rapid identification of Clostridium species by high-pressure liquid chromatography. Journal of Clinical Microbiology 22: 962967.

Jantzen E, Bryn K 1985 Whole-cell and lipopolysaccharide fatty acids and sugars of gram-negative bacteria. In: Goodfellow M, Minnikin D E (eds) Chemical methods in bacterial systematics. Society for Applied Bacteriology Technical Series. Academic Press, London, pp 145-171.

Jantzen E, Bryn K, Bergan T, Bovre K 1974 Gas chromatography of bacterial whole cell methanolysates. V. Fatty acid composition of Neisseriae and Moraxellae. Acta Pathologica et Microbiologica Scandinavica, Section B : Microbiology 82 : 767-779.

Kamme, C, Vang M, Stahl S 1983 Transfer of $\beta$-Lactamase production in Branhamella catarrhalis. Scandinavian Journal of Infectious Diseases 15: 225-226.

Kingsbury D T 1967 Relationship between sulfadiazine resistance and the failure to ferment maltose in Neisseria meningitidis. Journal of Bacteriology 94 : 557-561.

Malmvall B E, Brorsson J E, Johnsson J 1977 In vitro sensitivity to penicillin $\mathrm{V}$ and $\beta$-Lactamase production of Branhamella catarrhalis. Journal of Antimicrobial Chemotherapy 3: 374 375.

Mead G C 1971 The amino acid-fermenting clostridia. Journal of General Microbiology 67: 47-56.

Ninane G, Joly J, Kraytman M 1978 Bronchopulmonary infection due to Branhamella catarrhalis: 11 cases assessed by transtracheal puncture. British Medical Journal 1 : 276278.

Otero R B 1972 Transformation of a lys-auxotroph to prototrophy in Neisseria catarrhalis. Experientia 28: 484-485.

Shah H N, Al-Jalili T A R, Elhag K M, Mundegar Z R 1987 Glucose-6-phosphate dehydrogenase and malate dehydrogenase enzyme electrophoretic patterns amongst strains of Bacteroides fragilis. Journal of General Microbiology 133: 1975-1981. 